\title{
Key account management as a firm capability
}

\begin{abstract}
Firms manage numerous inter-organizational relationships. Key account management (KAM) is a concept used to manage a specific subset of these relationships, i.e. a supplier firm's relationships with strategically important customers. Scholars have studied different elements of KAM such as actors, resources, or relationships. Surprisingly few studies discuss the link between KAM and competitive advantage. By adopting a capability perspective on KAM, we seek to develop a theoretical basis to better explain its performance-implications. The capability perspective is compatible with extant approaches and complements them with new arguments concerning the value that a KAM system has in competition. The purpose of our article is to develop a conceptual model of a supplier firm's KAM capability and to indicate avenues for future research.
\end{abstract}

Keywords: Key account management; Substantive capability; Dynamic capability;

Framework. 


\section{Key account management as a firm capability}

\section{Introduction}

Firms usually need to handle multiple inter-organizational relationships with value creation partners, such as suppliers, alliance partners, R\&D partners, or customers (Morgan \& Hunt, 1994; Ring \& Van de Ven, 1994). Key account management (KAM) refers to the management of a specific subset of these inter-organizational relationships, i.e. relationships with those customers of the firm who have the highest level of strategic importance for the firm's long-term performance (Ivens \& Pardo, 2007; Pardo, Ivens, \& Wilson, 2014). While these relationships represent a small number of all the relationships of the firm's relationship portfolio, they typically contribute a substantial proportion to the firm's revenue and profit.

KAM has been a topic of academic research for over thirty years (Guesalaga \& Johnston, 2010; Ivens \& Pardo, 2015). Conceptual discussions as well as empirical research have focused on a variety of aspects related to KAM. For example, prior work has examined various dimensions of KAM (Gounaris \& Tzempelikos, 2014; Guesalaga, 2014), actors such as the individual key account (KA) manager or KAM teams (Atasanova \& Senn, 2011; Speakman \& Ryals, 2012), and the organizational implementation of KAM in structural dimensions, in processes, or in a specific organizational culture (Guenzi \& Storbacka, 2015; Leischnig, Ivens, Niersbach, \& Pardo, 2017; Storbacka, 2012).

Yet, extant studies differ in the degree to which they put an emphasis on strategic as opposed to operational aspects of KAM. Fundamentally, the KAM literature is strategically oriented per se, as each KAM concept has links to a firm's customer strategy. In this perspective, Gosselin and Gauwen (2006, p. 381) note that "[c]ustomer-supplier interactions will move toward a strategic relationship for the supplier when rent generation is high”. Achieving superior rent generation is a core objective in KAM and often a central motive for its introduction, too. While extant research has improved the understanding of several 
components or building blocks of KAM, the strategic perspective that explains how KAM contributes to occupying marketplace positions of competitive advantage and, hence, achieving superior firm performance still requires stronger attention. As Gosselin and Gauwen (2006, p. 377) observe, the "literature on account management shows limited research from an organisational or strategic perspective".

We argue that KAM research would profit from an integrative strategic perspective that permits managers to understand the prerequisites for an effective and efficient KAM programme and, at the same time, provides a general framework for empirical research on KAM performance. We suggest that the capability literature provides such a strategic lens and offers a focal point or pivot around which research may be organized. Given that in some firms there is still some doubt about KAM's contributions to firm performance and a feeling that investments into KAM may not lead to adequate returns, the capability perspective could provide a coherent framework to explain how and why KAM can create value for firms. We also suggest that an integrative account is relevant, because as long as individual aspects of KAM are studied through different lenses, research findings may develop incommensurable patterns that obscure a coherent big picture. Different frameworks or theories have different explananda and explanantia (e.g. Hunt, 1983), with each of them relevant and appropriate for a specific research question. In KAM research, however, the scope of theories and frameworks used until today is very broad, ranging from economics through organization theory to psychology and sociology. Studies use different languages and not all of them make it clear how they link back to competitive advantage and firm performance. An overarching framework would allow the integration of insights provided by different research streams and would clarify how they relate to different KAM capabilities that, in turn, influence firm performance.

This study argues that an influential and important school of thought from the field of strategic management may provide such a framework: the broad and fast growing stream of 
literature anchored in the substantive capabilities and dynamic capabilities view of the firm. This school of thought has not received much attention from KAM scholars, which is astounding because KAM - in its very nature - is a strategic management concept (MarcosCuevas, Nätti, Palo, \& Ryals, 2014; Sullivan, Peterson, \& Krishnan, 2012). The primary questions of this article are whether KAM can be considered a strategic capability of firms and, if so, to what extent KAM represents a substantive and/or dynamic capability? This study argues that KAM has the potential to represent a substantive capability and that, under certain circumstances, it also represents a dynamic capability. This article attempts to make two primary contributions. First, this research discusses and clarifies the compatibility of the capability view with KAM. Second, it outlines the nature of firms' KAM capability by providing a conceptualization that spans the levels of individual relationships with KAs as well as the level of a firm's KAM programme.

The remainder of this article is organized as follows: First, we review the KAM literature with respect to theoretical paradigms employed in extant research. Second, we introduce the notions of substantive capabilities and dynamic capabilities. Next, we develop a conceptual model of KAM as substantive and potentially dynamic capability. Finally, we discuss the value of our model and develop avenues for future research that our model provides.

\section{Theoretical perspectives on KAM}

KAM is a form of boundary-spanning marketing organization (Hult, 2011) and an idiosyncratic management approach that is adopted by firms in order to manage a specific subset of customers in their customer portfolio, i.e. customers who have strategic importance for the long-term performance of the firm. These customers are strategic in nature because they are essential for the future development of the firm, for example because they represent outstanding opportunities for growth (Davies \& Ryals, 2014; Homburg, Workman, \& Jensen, 
2002), or because cooperating with these customers allows the supplier firm to progress in value co-creation (Hakanen, 2014), or because doing business with these customers involves high levels of business risk (Lacoste \& Blois, 2015).

As such, KAM is part of the firm's sales activities (Pressey et al., 2014). KAM often coexists besides classical field sales organizations, e- and m-channels, or call centre-based sales activities. However, KAM differs from such and other sales approaches through the diminished relative importance of the sales task. Compared with sales actors, KA managers spend much less time in actual selling activities. Instead, their job profiles are typically more complex and comprise strategic activities such as comprehensive KA analysis, or medium- to long-term KA planning (Davies, Ryals, \& Holt, 2010, Davies \& Ryals, 2013).

Researchers interested in KAM have drawn on various conceptual frameworks to structure the field and develop and test hypotheses. While some of the frameworks can be considered as theories in the sense that they propose "systematically related sets of statements, including some law-like generalizations, that are empirically testable" (Hunt, 1983, p. 10), others are more descriptive in nature and do not formulate such related sets of statements. Still, they define a framework including categories that allow structuring empirical observations, or they propose useful constructs such as "robust categories that distil phenomena into sharp distinctions that are comprehensible to a community of researchers" (Suddaby, 2010, p. 346).

Among the theoretical lenses that have been employed in KAM research are the actorresources-activities perspective (e.g. Homburg et al., 2002), the relational norms perspective (e.g. Ivens \& Pardo, 2006), the relationship value perspective (Ulaga \& Eggert, 2006), the resource-advantage theory (e.g. Arnett, Macy, \& Wilcox, 2005; Ivens \& Pardo, 2007), and theories of organizational alignment (e.g. Pardo et al., 2014; Richards \& Jones, 2009; Storbacka, 2012). The theoretical lenses employed in KAM research have their roots in different disciplines and they are heterogeneous with respect to their domains, constructs, 
relationships between constructs, and degree of generalizability. A researcher's choice of the specific theoretical lens adopted for KAM research depends on the focus and purpose of his or her study. For a given research focus, a specific theoretical lens may prove to be more useful while other lenses may not show a strong fit with the same endeavor. Different research foci exist (Richard \& Jones, 2009), and current KAM research reflects at least the following.

Individual-level studies focus on KA managers or teams, their characteristics, and their performance (e.g. Vafeas, 2015). Studies adopting this perspective often have their roots in psychology and related disciplines and focus on, for example, what traits facilitate KA managers' work. They have produced lists of activities that KA managers perform (e.g. Davies \& Ryals, 2013). Moreover, they discuss skills and capabilities required by KA managers (e.g. Sengupta, Krapfel, \& Pusateri, 2000).

Relationship-level studies focus on the effects of KAM at the level of the supplier-KA relationship or network (e.g. Friend \& Johnson, 2014; Hakanen, 2014) and examine the supplier firm's success in managing the KA relationship involving the KA manager as well as other actors working at the supplier-KA interface (e.g. Richards \& Jones, 2009) and taking into account contingency factors (e.g. Alhussan, Al-Husan, \& Chavi, 2014).

Organizational-level studies focus on how firms implement KAM programmes across individuals and relationships. They examine how the structural and procedural organization of the firm or the formalization of activities in the firm affect KAM performance at the organizational level, i.e. the aggregated success of a KAM programme across supplier-KA relationships and the actors involved. Several lenses have been used to study KAM at the organizational level, such as the actors-resources-activities framework (e.g. Homburg et al., 2002), or differentiation-alignment theory (Lawrence \& Lorsch, 1969) and frame alignment theory (Goffman, 1974) that, for example, Pardo, Ivens, and Wilson (2014) use. 


\section{Resource-oriented concepts, substantive capabilities, and dynamic capabilities}

\subsection{Resource-oriented concepts}

The resource-based view and related streams of research have focused on several concepts that are core to its line of thought as well as to this study. In order to clarify these concepts for the remainder of this article, we provide a short overview of these core concepts. We follow the conceptualizations suggested by Day (1994) and Hooley, Saunders, and Piercy (2008), who propose that resources encompass assets and capabilities. Assets are "the resource endowments of the firm", while capabilities represent "the glue that binds assets together" and that "facilitates their effective deployment in the market place" (Hooley, Broderick, \& Möller, 1998, p. 508). Skills and competencies are knowledge and learning related elements that, when bundled in specific ways, form capabilities (Hooley, Broderick, \& Möller, 1998).

\subsection{Substantive capabilities}

The capability concept emerged when scholars in strategic management suggested explanations for firm performance that are located within a firm, such as the resource pool available to a firm (e.g. Barney 1991; Penrose 1959; Peteraf 1993). Yet, the capability perspective extends beyond the classical resource-based view and its argument that performance is enhanced when a firm possesses or controls a certain number of tangible or intangible assets that are valuable, rare, inimitable, and non-substitutable (Barney 1991; Nelson \& Winter, 1982). Substantive capabilities (or zero-order capabilities) are routines through which a firm transforms resources into outputs and creates value for the firm as well as for its stakeholders in a given market context (Morgan \& Slotegraaf, 2012; Schilke, 2014a; Teece, Pisano, \& Shuen, 1997; Vorhies \& Morgan, 2005). Routines consist of "behavior that is learned, highly patterned, repetitious, or quasi-repetitious, founded in part in tacit knowledge" (Winter 2003, p. 991). They encompass "formal and intentional efforts as well as 
informal and unreflected actions by organizational participants in their daily work" (Schriber \& Lowstedt, 2015, p. 55). A substantive capability thus represents a bundle of organizational knowledge that is combined with individuals' skills and tangible as well as intangible resources in the context of a business process that enables the firm to "earn a living in the present" (Schilke, 2014a, p. 369). Through substantive capability-controlled transformation routines, firms change, alter, reconfigure, integrate, or combine resources (Eisenhardt \& Martin, 2000). A clear distinction exists between substantive capabilities on the one hand, and the processes on the other hand; substantive capabilities enable processes to be carried out in an effective and/or efficient manner (Day 1994).

Several authors have developed taxonomies to classify capabilities. These taxonomies comprise dimensions such as the unit of analysis (e.g. individual, group, organization, or inter-organizational level; Morgan \& Slotegraaf, 2012), the hierarchical scope of a capability (e.g. specialized vs. architectural capabilities, Vorhies \& Morgan, 2005), or its directional logic (e.g. inside-out, outside-in, or spanning; Day, 1994). For managers, capability taxonomies provide a helpful structure to analyze the business processes that they need to alter to improve their firm's competitive position. For researchers, the taxonomies help identify categories and hierarchies of substantive capabilities for the purpose of empirical research. Because evidence connecting specific types of substantive capabilities with superior firm performance is "relatively sparse" (Morgan \& Slotegraaf, 2012, p. 101), more research is still needed. Marketing research has the potential to provide important insights with respect to the role of market-related capabilities for firm performance.

While the potential importance of substantive capabilities has been repeatedly recognized, many authors argue that this classical capability-centred perspective alone does not take into account disruptive technological, social, and other changes that affect many industries (e.g. Day 2011). As a consequence, the dynamic capability view has evolved. This 
complementary view focuses on higher-order capabilities, such as first-order capabilities (e.g. Helfat \& Winter, 2011) or second-order capabilities (e.g. Collis, 1994).

\subsection{Dynamic capabilities}

Teece and Pisano (1994, p. 541) initially defined dynamic capabilities as a "subset of the competences/capabilities which allow the firm to create new products and processes and respond to changing market circumstances". Zollo and Winter (2002) argue that this definition was insufficient to make a clear distinction between substantive (zero-order) and dynamic (first-order) capabilities. They define a dynamic capability as "a learned and stable pattern of collective activity through which the organization systematically generates and modifies its operating routines in pursuit of improved effectiveness" (Zollo \& Winter, 2002, p. 340). When markets are dynamic (i.e. rapidly changing and unpredictable), firms need to develop an ability to adjust their resource base quickly to maintain a high level of performance. As Augier and Teece (2009, p. 412) note: "if a firm possesses resources/competences but lacks dynamic capabilities, it has a chance to make a competitive return for a short period, but superior returns cannot be sustained"..

Hence, dynamic capabilities are organizational and strategic routines through which firms alter their resource base — acquire and shed resources, integrate, and recombine themto generate new value-creating strategies (Pisano, 1994). Dynamic capabilities “determine the speed at, and degree to which, the firm's particular resources can be aligned and realigned to match the requirements and opportunities of the business environment so as to generate sustained abnormal (positive) returns" (Teece, 2012, p. 1395).

Eisenhardt and Martin (2000) specify four characteristics of dynamic capabilities. First, dynamic capabilities consist of strategic and organizational processes that create value for firms by manipulating resources into new value-creating strategies. Secondly, these capabilities exhibit commonalities across effective firms. Thirdly, effective patterns of 
dynamic capabilities vary with market dynamism. When markets are moderately dynamic such that change occurs in the context of a stable industry structure, dynamic capabilities resemble the traditional conception of routines (e.g. Nelson \& Winter, 1982). That is, they are complicated, detailed, analytic processes that rely extensively on existing knowledge and linear execution to produce predictable outcomes. In contrast, in highly dynamic markets in which industry structure is blurring, dynamic capabilities take on a different character. They are simple, experiential, unstable processes that rely on quickly created new knowledge and iterative execution to produce adaptive, but unpredictable outcomes. Finally, dynamic capabilities arise from learning. Learning mechanisms guide the evolution of dynamic capabilities and underlie path dependence. Learning mechanisms are seen as "second order" dynamic capabilities to the extent that they "shape operating routines directly as well as by the intermediate step of dynamic capabilities" (Zollo \& Winter, 2002, p. 340).

As is the case for substantive capabilities, the concept of "routines" occupies a central role in the dynamic capabilities view (Eisenhardt \& Martin, 2000; Feldman \& Pentland, 2003; Zollo \& Winter, 2002). The micro-foundations of dynamic capabilities, that is, skills, processes, rules, structures etc., are difficult to develop and deploy. Teece (2007, p. 1319) argues that firms with a strong entrepreneurial focus have higher levels of dynamic capabilities which, in turn, allow them to not only adapt to new market contexts, but also "shape them through innovation and through collaboration with other enterprises, entities, and institutions". An important part of a firm's dynamic capabilities resides in the top management team and is influenced by existing processes and structures (Teece, 2007).

At the same time, dynamic capabilities themselves can be considered as routines. Zollo and Winter (2002) call them "search routines". Recently, Teece (2012) challenged, or at least refined, the role that routines have in the dynamic capability view of the firm. He considers that while routines play a role for dynamic capabilities, "particular (non-routine) actions by top management" (Teece, 2012, p. 1400), such as prioritizing new projects that bring about 
challenges the organization has not been confronted with in the past, are highly important, too. Teece's (2012) emphasis on certain management skills that sustain dynamic capabilities appears fully compatible with our perspective. This author (2012, p. 1398) sees the focus of these skills in asset orchestration, which he defines as "asset alignment, coalignment, realignment, and redeployment". He considers them "necessary to minimize internal conflict and to maximize complementarities inside and outside the enterprise" (Teece, 2012, p. 1398).

In summary, the capability view offers a sound perspective on how routines and the capability to alter routines have strategic importance for the long-term performance of firms. Firms need to identify those routines that, in its specific market environment, are relevant and determine long-term performance. We posit that for many firms, in particular on business markets, KAM represents an essential approach that can be conceptualized as a set of capabilities.

\section{Extant research on business relationships, KAM, and capabilities}

\subsection{Business relationships and the capability view}

With respect to business relationships, contributions that draw on the capability view exist in several areas. They concern both dyadic relationships and networks of relationships and cover horizontal as well as vertical relationships. The following sections provide a brief overview over predominant concepts.

Network and networking capabilities. A first stream of literature is concerned with fundamental characteristics of capabilities in inter-organizational relationships. Authors mainly discuss routines located at the organizational level in order to manage sets of relationships or business networks (Araujo, Gadde, \& Dubois, 2016; Forkmann, Henneberg, Naudé, \& Mitrega, 2016; McGrath \& O’Toole, 2013; Mitrega, Forkmann, Ramos, \& Henneberg, 2012). 
Relationship life-cycle capabilities. This stream of research is interested in capabilities required to manage instabilities and ambiguity in business relationships and networks. Relationships and networks are often turbulent phenomena that cannot be fully controlled by a focal company (Ford, Gadde, Hakansson, \& Snehota, 2003). Recently, the management literature began addressing this issue from different angles, thereby considering such issues as ending competence (Havila \& Medlin, 2012; Ritter \& Geersbro, 2011; Zaefarian et al., 2016), developing partners (Wagner, 2006), and dynamic networking capabilities (Mitrega et al., 2012).

Relationship-dedicated vs. network-dedicated capabilities. Capabilities devoted to B2B partnering may be dedicated to a single relationship and help the focal company to exploit this partnership, including mitigating disturbances. However, such capabilities may be also devoted to the overall relationship portfolio management to diversify relationship benefits and risks (Capaldo, 2007; Lavie, 2007; Mitrega et al., 2012; Mitrega et al., 2017). Furthermore, a company may develop and implement practices and representations (i.e. cognitive tools such as network pictures) to strategize within the whole industrial network that surrounds it, including both direct and indirect partners (Henneberg, Mouzas, \& Naudé, 2006; Thornton, Henneberg, \& Naudé, 2014).

Context-specific relational and network capabilities. Network management tasks differ contingent on the network type in which a company is embedded (Järvensivu \& Möller, 2009). For example, institutional influences (e.g. national cultures or regulatory systems) can affect the nature and shape of firms' relational capabilities. Studies of national culture clusters suggest that such capabilities tend to have a rather personal character in certain cultures, e.g. 'guanxi' in China and 'blat' in Russia (Gu, Hung, \& Tse, 2008; Michailova \& Worm, 2003). Another research stream focuses on relational capabilities in SMEs (e.g. Kenny \& Fahy, 2013). 
Alliance management capabilities. In order to manage horizontal or lateral relationships with strategic partners, some firms dedicate a position to coordinate all alliance- and relationship-related activities within the firm (Kale \& Singh, 2007; Ivens et al., 2009). Firms' motives for the formation of alliances include factors such as learning from partners, obtaining access to technology and complementary resources, or enhancing innovativeness (e.g. Geigenmüller \& Leischnig, 2017). Research on alliance management has studied how these objectives may be reached (e.g. Bozemann 2000) and a relational view on alliance management capabilities provides valuable insights (Leischnig et al., 2014).

\subsection{KAM and the capability view}

In the stream of literature that focuses specifically on KAM, the capability perspective has found rather limited consideration so far. Nevertheless, a small number of articles exist. They discuss different types of capabilities from different vantage points.

A first group of articles focuses on lower-order capabilities in the form of skills required by KA managers (e.g. Atanasova \& Senn, 2011; Gounaris \& Tzempelikos, 2014). Prior studies provide broad lists of skills that KA managers should have to perform their job effectively (e.g. customer analysis, team management and leadership, etc.) (Cheverton, 2008; Sengupta et al., 2000).

A second group of articles establishes links between KAM and higher-order capabilities. For example, Hui Shi et al. (2004) focus on global account management (GAM) as a form of KAM that specifically addresses customers that are served on a worldwide basis. They position their work at the level of the individual supplier-global account relationship and identify three distinctive capabilities, namely, collaborative orientation, strategic fit, and configuration. These authors argue that GAM-related capabilities have positive effects on GAM performance outcomes. Moreover, they assume that goal congruence and 
complementary resources constitute facilitating conditions for GAM-related capabilities to emerge.

In a similar vain, Storbacka (2012, p. 259) defines KAM (referred to as strategic account management in his article and,drawing from the capability perspective) as "a relational capability, involving task-dedicated actors, who allocate resources of the firm and its strategically most important customers, through management practices that aim at interand intra-organizational alignment, in order to improve account performance (and ultimately shareholder value creation)". KAM is conceptualized as a management concept comprising two groups of design elements, i.e. inter-organizational alignment elements and intraorganizational design elements. Each group consists of four sub-elements. One of these elements is referred to as support capabilities.

A third capability-focused contribution to the KAM literature is a study by Tzempelikos and Gounaris (2015), who identify a set of key KAM practices. They examine how these practices explain the performance of KAM through the mediating effect of the supplier's relational capabilities and the relational outputs that such capabilities produce. The results show that the identified practices positively affect performance and dyadic outcomes through the mediation coming from relational capabilities.

Comparing these studies, several observations can be made. First, while Storbacka (2012) locates KAM capabilities at the organizational level, Hui Shi et al. (2004) locate them at the relationship level, and Tzempelikos and Gounaris (2015) distinguish between KAM processes and the supplier firm's relational capabilities. Secondly, none of the studies clarifies whether the capabilities they discuss constitute substantive or dynamic capabilities or architectural or specialized capabilities, and to what extent the capabilities encompass insideout, outside-in, and spanning processes. Against this background, this study proposes an integrative perspective of KAM that integrates extant capability typologies and the capabilitybased KAM literature. For this purpose, it develops a definition of firms' KAM capability and 
it suggests a conceptual framework of KAM capability that differentiates several building blocks.

\section{Defining KAM as a supplier firm capability}

This study suggests that under certain conditions firms have the possibility to occupy marketplace positions of competitive advantage by developing a capability in the field of KAM. Firms implement KAM for strategically important customers, i.e. when the opportunities for achieving superior rents and hence gaining competitive advantage are superior for certain customers as compared to others (Piercy \& Lane, 2006). Not all markets are of this sort. There are markets where such customers do not exist. In order to point out clearly what the characteristics of this capability are, we combine elements of definitions from Winter (2000, 2003) and Feldman and Pentland (2003) with fundamental characteristics of

KAM. We define a firm's KAM capability as:

a collection of routines, that is, repetitive, recognizable patterns of interdependent actions, used to manage strategically important customers, involving multiple actors as well as input flows and conferring upon the firm's management a set of decision options for producing significant outputs of a particular type with the firm's key customers.

This definition implies the following. First, a firm's general KAM capability is a collection of routines, that is, it is an agglomerate of partial capabilities. These partial capabilities concern two different levels of an organization. The first level is that of the organization that implements a KAM programme (Mitrega et al. 2012; Morgan \& Slotegraaf, 2012; Storbacka, 2012). This may be a firm, a division, a business unit, or any other unit of economic action. At this level, the general scope of the KAM programme is defined. The general scope includes, for example, the decision whether the programme is a national account management programme, an international account management programme, or a 
global account management programme. It comprises routines for handling repetitive, recognizable patterns of interdependent actions such as the process of defining which customers receive KA status or the definition of profiles of skills that KA managers need to have. The second level at which KAM capabilities apply is the individual KAM relationship (Hui Shi et al., 2004; Morgan \& Slotegraaf, 2012). It comprises routines for handling repetitive, recognizable patterns of interdependent actions such as establishing an accountspecific strategic plan or developing a KA-specific offering of prices, terms and conditions. A firm's KAM capability, as defined here, does not encompass individual personal skills of employees working in KAM. While we acknowledge the existence of such skills, we do not interpret them as organizational KAM capabilities. Rather, they constitute skills required by individual actors involved in KAM to produce relevant outputs as defined in a firm's KAM strategy. The personal skills of individual KAM actors become valuable through their integration in organizational KAM capabilities, for example through KAM trainings. Hence, this study interprets individual KAM skills as conceptually distinct from a firm's organizational KAM capability.

Secondly, the capability combines actors and flows of input resources with the aim of producing significant outputs of predefined types. The ultimate purpose of KAM is to create value for both the supplier firm and the KA. Depending on the type of value objectives the supplier firm pursues through the implementation of a KAM programme (e.g. accelerated cash flows, enhanced cash flows, reduced volatility and vulnerability of cash flows, or enhanced residual value of cash flows, Srivastava, Shervani, \& Fahey, 1998), different combinations of actors and resources may be required. The better developed a firm's KAM capability is (i.e., its collection of relevant KAM routines), the better managers understand which actors and resources need to be combined to achieve KAM-related value objectives. Managers' understanding of the respective routines is related to repetitious or quasi- 
repetitious patterns of KA-related behaviour founded, in part, in tacit knowledge (Winter, 2003).

Thirdly, the capability confers a set of decision options upon the firm's management. Winter (2000, p. 983) explains that "the 'set of decision options' language" underscores the fact of managerial control over the "large chunk of activity that clearly matters to the organization's survival and prosperity" and that represents the KAM capability. Hence, management is able to design the activities encompassed by a KAM capability. The capability can be actively developed and some firms are better at developing a KAM capability than others. Yet, routine-based capabilities are path-dependent (Becker, 2004). They build on past behaviours and experiences. Even though capabilities may adapt over time, they do so based on the patterns they have taken in past situations (Levitt \& March, 1988).

Fourthly, the KAM capability involves routines that are required when managing strategically important customers. Hence, a firm's KAM capability is neither identical with its general marketing capability, nor with a firm's sales management capability. Instead, KAM constitutes an idiosyncratic domain and a firm's KAM capability is conceptually and practically distinct from the capabilities required in other fields of market-oriented management (e.g. managing large numbers of rather anonymous customers through customer interaction centers).

Finally, firms implement KAM to produce outputs of a particular type. Salojarvi and Saarennko (2013) observe that, in general, only a few researchers have considered performance implications of KAM implementations adopted by supplier firms. The outputs and outcomes achievable through a KAM capability are situated on different levels of abstraction. At the highest level, they reside in contributions to firms overall performance and the building and sustaining of competitive advantage. At lower levels they consist of more tangible outputs. For example, Homburg, Workman, and Jensen (2002), along with Cespedes (1993), acknowledge that KAM has outcomes not only with respect to key accounts but also 
at the organization level (i.e. adaptiveness, performance in the market, and profitability). Another possible perspective at this level of outcomes is the one suggested by Srivastava, Shervani, and Fahey (1999), i.e. accelerated cash-flows from KAs, enhanced cash-flows from KAs, and reduced vulnerability and volatility of cash flows achieved with the firm's KAs. At yet lower levels of abstraction, these objectives can be broken down into tangible outputs achieved in different fields in the relationship with the firm's KAs (e.g. improved outputs in different product categories the KA buys, in different geographic areas in which the firm does business with the KA, etc.), always with respect to cash flows from KAs.

Based on this definition of a firm's KAM capability, we develop a framework describing this capability in a more detailed way. Specifically, the framework identifies a set of specific KAM capabilities. This framework lays the grounds for formulating directions for future research on firms' KAM capability.

\section{A framework of KAM as a firm capability}

\subsection{Overview of the KAM capability framework}

Based on the definition of KAM as a firm capability, this study proposes the framework shown in Table 1. The framework distinguishes specific KAM capabilities under the conceptual roof of a firm's general KAM capability and shows two primary dimensions. The first dimension encompasses two categories, that is, KAM at the level of the individual supplier-account relationship and KAM at the organizational level (Hui Shi et al., 2004; Mitrega et al., 2012; Morgan \& Slotegraaf, 2012; Storbacka, 2012). The second dimension incorporates three categories, i.e. the outside-in, spanning, and inside-out capabilities as discussed by Day (1994). The model proposes that all three of these capabilities apply at both levels, of the first dimension, that is, the relationship and the organization. Hence, the model suggests six specific capabilities that, taken together, constitute a firm's overall KAM capability. Besides, it considers KAM support capabilities. 


\section{Insert Table 1 about here.}

\subsection{Relationship-level KAM capabilities}

The first capability this study identifies is the relationship-level outside-in capability (RLOI). This capability consists of two types of routines. The first type of routine has the purpose to link "the processes that define the other organizational capabilities" (Day, 1994, p. $41)$ to the KA's needs and expectations (Homburg, Wiesecke, \& Bornemann, 2009) and identify future customer requirements ahead of competitors, sometimes even ahead of the customer firm itself. The second type of routine seeks to maintain and strengthen the relationship with the KA and the members of the KA's firm (Greenley, Hooley, \& Rudd, 2005). These routines "exhibit many of the characteristics of sustainable competitive advantage creation” (Hooley, Greenley, Cadogan, \& Fahy, 2005, p. 22). Both routines together aim to establish a stable, close, and cooperative link between the supplier firm and the KA through which the supplier firm's KAM is able to provide superior value creation for the KA firm.

The relationship-level inside-out (RLIO) capability constitutes the second building block of firm's overall KAM capability. It is activated by customer requirements formulated by the specific KA, activities competitors deploy around this KA, and opportunities the KA manager, KA team, and other actors identify with respect to the specific KA (Day, 1994; Ulrich \& Lake, 1990;). The RLIO capability comprises processes such as KA-specific integrated logistics concepts (e.g. just-in-time systems) or KA-specific manufacturing processes (e.g. in a dedicated factory, located next to the customer's production site, such as in many automotive OEM-tier 1 supplier relationships) (Day, 1994, Fahy, Hooley, Cox, Beracs, Fonfara, \& Snoj, 2000). This capability requires that KA managers and KAM teams understand the supplier's specific configuration of internal resources and capabilities as well 
as resources and capabilities available to the supplier firm through partnerships with other organizations. Moreover, they need to be able to mobilize these resources and capabilities for their specific KA.

The relationship-level spanning (RLS) capability connects the RLOI and RLIO capabilities and ensures the effectiveness and efficiency of KAM at the level of each individual supplier-KA relationship. Spanning routines are important in processes linking inputs from a KA (e.g. wishes, expectations, or ideas for projects) and the supplier firm (wishes, expectations, ideas for projects), e,g, in the form of enhanced customer service activities from the supplier or joint development teams in R\&D projects (Bush, Smart, \& Nichols, 2002). The RLS capability reflects routines in which the KA manager, potentially together with a KAM team (e.g. Workman, Homburg, \& Jensen, 2003; Lai \& Gelb, 2015), orchestrates the activities of other actors from specialized functional units on both the supplier and KA side of the relationship. KA managers and KAM teams identify, for a given issue such as customer service enhancement, which actors from both sides are required to interact with each other. They establish contacts, help in agenda setting, and accompany the interaction process without necessarily being present at every interaction in person. However, they need to remain informed about the current state of contacts and they intervene for trouble shooting or similar tasks when necessary. A second example for a RLS capability is the account planning process. Here, KA managers and KAM teams develop a KA-specific strategic and operational plan that specifies what internal resources and actors (or RLIO capabilities) are required at what moment of a business year for what account-specific purpose and what budget is allocated to this activity and these actors. The planning process takes place on the basis of KA analyses conducted by KA managers, KAM teams, and other specialists (i.e. the RLOI capability). It leads to the formulation of the account-specific value proposition (Storbacka, 2012). Through the RLS capability, RLIO and RLOI capabilities become aligned for one specific KA. 


\subsection{Organization-level KAM capabilities}

Since most firms define more than one customer as KA, the higher-level capability required in KAM is to design, coordinate, and monitor the KAM programme as a whole, including all actors, activities, and resources (e.g. Homburg et al. 2002, Storbacka 2012). In line with the networking capability view (e.g. Mitrega et al., 2012), we interpret organizationlevel KAM capabilities as routines to ensure the coherence of decisions concerning the overall design of a firm's KAM programme.

The organization-level outside-in capability (OLOI) refers to a supplier firm's monitoring of the more general environment of its KAM programme. It encompasses two main facets. Market sensing refers to the monitoring of general market requirements with respect to KAM treatment. The perspective is across the firm's KA relationships. It helps the supplier firm understand general customer expectations with respect to suppliers' KAM programmes (e.g. the role of product, logistics, or IT adaptation for strategically important customers on a given market). Secondly, competitor sensing refers to understanding the design of competitor KAM programmes (e.g. which competitors use a KAM programme, or whom do competitors design as KAs). The OLOI capability ensures that a supplier's KAM programme is aligned with the market's challenges and that the firm disposes of all relevant information to design the specific configuration of its KAM programme such as KA selection criteria to identify KAs or define the number of KAs.

The organization-level inside-out (OLIO) capability constitutes the second building block of a firm's KAM programme coordination capability. It is activated by requirements that are specific for the firm's KAs and that differ from regular customers' requirement such as developing specific manufacturing approaches, supply chain solutions, or other adaptations of value activities. Technological advances achieved within the supplier firm may trigger the OLIO KAM capability, activities competitors deploy around their KAs, or opportunities the 
KA managers, KA teams, and other actors identify with respect to their KAM programme in general (Day, 1994; Ulrich \& Lake, 1990). Finally, this routine also encompasses the firm's capability to control its KAM programme through performance indicators and other appropriate means and, hence, to dispose of qualified information allowing strategic audits of the KAM programme.

The organization-level spanning (OLS) capability connects the OLOI and OLIO capabilities of KAM and ensures the effectiveness and efficiency of KAM at the level of the organization's KAM programme. The OLS capability includes the development of the firm's general KAM strategy. The KAM strategy defines the objectives of the KAM programme, KAM activities or processes (e.g. in terms of formalization), and the resources available for the KAM programme (Hui Shi et al., 2004). Moreover, the OLS capability encompasses the management of the supplier firm's KA portfolio (Storbacka, 2012). This routine refers to the selection of KAs, the definition of relevant criteria, the use of information, and all related activities. Finally, the OLS capability comprises all activities of information dissemination about the KAM programme both within the supplier firm and among all relevant external stakeholders such as, for example, investors (Zhang, Vonderembse, \& Lim, 2002). KAM programmes are complex management concepts. Hence, challenges arise for stakeholders inside and outside of the firm to understand the objectives pursued through a firm's KAM programme and the more specific processes involved in KAM. To avoid barriers to and increase the efficiency and effectiveness of KAM programmes, KAM managers need to disseminate information about the programme that allows stakeholders to become involved in KAM activities.

\subsection{Support capabilities}

To enable the actors involved in the six partial KAM capabilities described above to reach their objectives, supplier firms need to implement KAM support capabilities (Shapiro \& 
Moriarty, 1984; Storbacka, 2012). These capabilities involve secondary activities that provide inputs to the principal building blocks of the firm's KAM capability on both the relationship level and the organizational level. For example, HR management is required at the relational level to ensure that all actors (i.e. KA managers, KAM teams, and actors from other functional units) dispose of the necessary knowledge and skills to perform their activities. HR needs to establish which skills are required, assess each actor's current level of skills, identify gaps, formulate training schedules to eliminate the gaps, etc. (Millman \& Wilson, 1996, Pardo, 1999; Ojasalo, 2001). Legal services are a further example. They are required in several situations in KAM. To implement KAM, the firm needs to ensure that KA managers have access to legal services when needed. Legal services are not part of the principal value proposition for the KA. Yet, without them several activities either cannot be completed or may not yield desired outcomes. In summary, several support capabilities are required in KAM. A clear definition of how the support capabilities link to the firm's KAM capability contributes to effectiveness and efficiency of KAM processes.

\subsection{Substantive and dynamic KAM capabilities}

So far, the discussion of the firm's KAM capability based on our framework has not addressed the question whether the specific capabilities that constitute a firm's overall KAM capability are substantive or dynamic in nature. This study proposes that the specific capabilities may all either function as substantive capabilities or as dynamic capabilities. Whether the six capabilities function "only" as substantive capability for a firm or whether they constitute dynamic ones depends on two factors.

At the level of the individual relationship, this issue is affected by the dynamism that characterizes the customer firm and its market(s). In line with Cyert and March, (1963) or Nelson and Winter (1982), this study argues that when KAs are moderately dynamic such that change occurs in the context of stable patterns, KAM routines resemble the traditional 
conception of substantive capabilities. That is, they are complicated, detailed, analytic processes that rely extensively on existing knowledge and linear execution to produce rather predictable outcomes. As compared to regular customer relationships, supplier-KA relationships are more complex, e.g. because they involve more actors, more complex organizations, or customer-specific adaptations of value activities that deviate from standard operating procedures in regular sales contexts. Despite this increased complexity, however, under low levels of customer relationship dynamism, RLOI, RLIO, and RLS capabilities maintain a substantive character. In contrast, in highly dynamic supplier-KA relationships in which customer structure, processes, behaviours, expectations, and the like are subject to change, KAM capabilities need to take on a different character. In such situations, they are rather experiential, unstable processes that rely on quickly created new knowledge about the KA and iterative execution to produce adaptive, but rather unpredictable outcomes (e.g. Winter 2003; Schilke 2014a, b). Learning mechanisms guide the evolution of dynamic capabilities in supplier-KA business relationships and these specific capabilities underlie path dependence.

At the organizational level, the question of the nature of KAM capabilities is influenced by the dynamism of the supplier firm's market environment. When markets are moderately dynamic such that change occurs in the context of stable patterns, organizational KAM (such as market sensing, KAM strategy development, or KA customer portfolio definition) routines resemble the traditional conception of substantive capabilities. For example, the supplier firm may rely on a stable set of criteria to evaluate customer firms and select those who receive KAM treatment. Under low levels of market dynamism, the use of a stable set of customer evaluation criteria in the portfolio analysis may lead to change in the number and type of KAs. However, the rate of change is low and it can be explained by well-known growth and decrease trends among customers on a given market. The firm's KAM capabilities still have a substantive character. In contrast, in highly unstable situations where the supplier's business 
model, target markets, customer portfolio structure, and the like are subject to frequent change, KAM capabilities need to take on a different character. For example, they may require new approaches define KAs. Consider, for example, the current change in the automotive industry where classical tier 1 suppliers (such as Bosch, Valeo, or Brose) face (potential) new entrants (such as Apple, Google, or Tesla) appear alongside their classical OEM KAs. At the same time, several tier 1 suppliers change their own strategy by redefining their business as mobility solutions for B2B, B2C, and B2A markets rather than the supply of components or systems to OEM car manufacturers. As a consequence, the OLIO, OLOI, and OLS capabilities take on a dynamic character. They become experiential, unstable processes that rely on quickly created knowledge about the new market environment (e.g. Winter 2003; Schilke 2014a, b). Learning mechanisms guide the evolution of these dynamic capabilities and they, too, underlie path dependence.

Hence, it is the level of dynamism surrounding the respective objects of analysis, i.e. a single supplier-KA relationship or the entire KAM programme, that will determine if a substantive capability is sufficient to maintain competitive advantage through a KAM programme. Under conditions of high dynamism, all specific KAM capabilities will take on a dynamic character. However, it is possible that while a general market environment remains rather stable and, hence, does not require dynamic capabilities, an individual KA is subject to dynamic change. In this case, the supplier firm may operate with a combination of substantive and dynamic capabilities. The dynamic capabilities will be required at the level of one particular KA relationship, whereas the KAM programme and other KA relationships can be successfully managed through substantive KAM capabilities.

\section{Discussion and avenues for future research}

This study attempted to answer two primary research questions. First, this research discussed whether KAM can constitute a firm capability and, if so, whether it represents a 
substantive and/or dynamic capability. Second, this study discussed the nature of firms' KAM capability and suggests a conceptualization that spans relationship- and programme-levels. This article defines KAM capability and develops a framework that details specific KAM capabilities assumed to represent building blocks of a supplier firm's overall KAM capability.

The framework developed in this study views KAM as a concept stretching across hierarchical levels, value activities, and functional areas. Each of the six specific KAM capabilities involves actors from one or several hierarchical levels and one or several functional units. Relationship-level capabilities focus on individual supplier-KA relationships and are mainly located at the level of the KA managers or the KAM teams. However, the KA managers and KAM teams sometimes need top-management involvement to mobilize resources and actors across the organization (e.g. Workman et al. 2003) to work towards the objectives the firm formulates for their specific supplier-KA relationship. They typically lack hierarchical power and, hence, depend on other sources of power to align KA and supplier expectations. Depending on the type of relationship-level capability (RLOI, RLIO, and RLS capabilities), different functional units, $R \& D$, finance, production, supply chain management, accounting, or customer service, different product-focused units, or geographic units, such as foreign subsidiaries, may be involved in the repetitive, recognizable patterns of interdependent actions concerned with KAM. Hence, the KA managers orchestrate a network of firm-internal actors as well as a network of actors on the KA side (Ivens, Pardo, Niersbach, \& Leischnig, 2016; Pardo, 1999). Relationship-level capabilities allow KA managers, KAM teams, and other actors involved in KAM to achieve relationship-level KAM objectives.

Organization-level routines concern the firm's KAM programme as a whole. Here, higher hierarchical levels, e.g. the CEO, CMO, CSO or KAM director of the supplier firm, are typically involved more directly in the three KAM routines reflected in OLOI, OLIO, and OLS capabilities. In addition, these KAM capabilities often rely on the participation of different functional, product-focused, or geographic units, too. However, each actor's 
contribution is more strategic in nature. Objectives encompass the establishment of a coherent approach to managing strategically important customers that mobilizes the right type and right amount of resources and that coordinates the activities executed by all actors. This permits ensuring the supplier firm's competitive position in the markets it competes in as well as its long-term economic performance. In this context, the OLS KAM might constitute the central core of a firm's KAM capability in that it refers to the most strategic management routines in KAM. Yet, we propose that, in itself, it represents a necessary but not a sufficient condition for KAM program performance. For the actual implementation of the strategic core, specific capabilities are required. Hence, future research will have to provide more detailed insights into interplay between specific KAM capabilities.

Developing a KAM capability is a challenging, complex task. Little is known about supplier firms' KAM capability in management practice and no empirical study has investigated KAM from a comprehensive, overarching capability perspective that encompasses the relationship level as well as the organizational level, so far. For this reason, the major contribution of this study is to structure the field of KAM from the capability perspective. In the past, KAM has been the object of numerous conceptual and empirical studies. These studies have focused on KAM actors, KAM processes, the structural implementation of KAM, and several other topics. However, the strategic contribution KAM can make to overall firm performance and competitive advantage has not been addressed extensively. We argue that this is due to the fact that few of the theoretical lenses taken in extant KAM research support studies examining the KAM implementation-KAM performance-firm performance link.

The capability view taken in this work provides a solid foundation for such studies. There are several research approaches that can help both scholars and managers develop a deeper understanding of KAM capabilities. On the conceptual level, while the present study provides the development of an overarching KAM capability framework, it does not discuss 
every possible relationship between KAM capability dimensions and other variables. Hence, future contributions could focus on specific aspects and develop more detailed conceptual propositions around firms' KAM capabilities. Moreover, because KAM capabilities constitute a young field of research (and because we do not yet know to what extent the capability as it is developed conceptually in this study can be observed in actual managerial practice), qualitative research could be conducted in order to gain a more profound understanding of issues such as how, why, when, and under what conditions KAM capabilities emerge.

Currently, many authors argue that better developed capabilities should lead to better firm performance. They also argue that this link is contingent on market dynamism (e.g. Helfat \& Winter, 2011; Zahra, Sapienza, \& Davidsson, 2006). Schilke (2014b) finds empirical support for this hypothesis in the context of alliance management. His results also suggest a non-linear relationship. The present study encourages scholars to empirically test the contingency assumption in the specific context of KAM. This study provides a framework that may constitute the point of departure for the development of scales that allow operationalizing a supplier firm's KAM capability for survey research. The literature provides operationalizations for several management and marketing capabilities, such as marketing exploitation and exploration capabilities (e.g. Vorhies, Orr, \& Bush, 2011; Morgan et al. 2012). Based on this know-how, reliable and valid scales measuring the specific KAM capabilities should be developed. Such scales would have the potential to provide KAM research with new possibilities, in particular with respect to studies examining the strategic dimension of KAM programmes.

In terms of empirical research, future studies of supplier firms' KAM capability have the potential to make several contributions to the KAM literature. First, there is a need for studies that attempt to identify empirical taxonomies of KAM capabilities. While some studies have looked at KAM from a taxonomic perspective (e.g. Homburg et al. 2002), the specific capability configurations that exist in KAM programmes in firms have not been 
studied so far. Yet, it is likely that different firms have developed different combinations of partial KAM capabilities. With novel empirical methods such as, for example, fuzzy-set Qualitative Comparative Analysis (fsQCA, e.g. Fiss 2011; Leischnig \& Kasper-Brauer, 2016; Ragin, 2008) - new possibilities for the identification of capability configurations exist today. We thus call for further research that contributes to a new perspective on KAM through the study of KAM capability configurations.

Moreover, we need a better understanding of the effects of KAM capabilities on performance outcomes. The capabilities view typically sees competitive advantage as "the key outcome variable in dynamic capabilities theory" (Schilke, 2014b). In the context of KAM and KAM capabilities, however, it is reasonable to assume that other outcome variables should be taken into account. Because of the more limited scope of a firm's KAM capability as compared to firms' overall capabilities, these variables will need to have a more limited scope than competitive advantage. At the relationship level, monetary and non-monetary performance variables for the individual supplier-KA relationship, such as dyadic competitive advantage or joint profit performance (Hui Shi et al. 2004) should be studied. At the organizational level, the success of a firm's KAM programme in general may be measured through different economic and non-economic indicators. We suggest that, in turn, the success of individual KAM relationships and of the KAM programme have a positive effect on competitive advantage and other firm-level performance variables.

Moderation and mediation in the relationships between KAM capabilities and performance outcomes constitute further avenues for further research. Besides environmental dynamism, additional variables may constitute moderators or mediators, for example KA managers' and other employees' level of KAM-specific skills. Identifying moderators and mediators in the KAM capability-KAM performance-firm performance causal chain is a particularly important endeavour if KAM scholars wish to formulate relevant managerial implications of their research. While it is important, from an academic vantage point, to 
understand if and how the fundamental causal chain is a phenomenon that is likely to hold true in empirical observation, managers operate under specific conditions and in specific situations. They need more precise knowledge about the factors that are relevant for the implementation and success of a KAM programme.

Finally, future research should also address the lack of knowledge concerning antecedents of KAM capabilities. Hui Shi et al. (2004) tackle this issue, but in a different perspective than those suggested herein. They are interested in inter-organizational capabilities as phenomena that are embedded inside a specific relationship. In their model, two constructs are assumed to function as facilitating conditions for inter-organizational global account management capabilities, that is, goal congruence and complementary resources. Hence, Hui Shi et al. (2004) stress the importance of including antecedent variables in empirical research on supplier firm's KAM capability. Yet, while we acknowledge that inter-organizational capabilities have a conceptual raison d'être, the antecedents they suggest do not fit closely with our perspective, that is, KAM as an organizational capability. We suggest that future research studies the effect of potential antecedents such as organizational culture, resource endowments, or industry characteristics. For practitioners as well as for scholars, such research would help us understand how KAM capabilities may be built up or may evolve.

Beyond these directions for future research on supplier firms' KAM capability, several other topics merit attention. For example, while there is a substantial stream of research on international business relationships (e.g. Burkert, Ivens, \& Shan, 2012; Gao \& Hui Shi, 2011), only a few studies have analyzed the impact of national culture on KAM and related practices so far. Hence, the question arises how culture may affect KAM capabilities. Depending on the national context or the type of relationship concerned, the actual role culture plays might differ. A second aspect would be to study the mirror side of KAM, i.e. key supplier management (KSM, Ivens, Van de Vijver, \& Vos, 2013; Makkonen \& Olkkonen, 2013). It 
would be interesting to consider whether the structure of a buying firm's KSM capability matches a supplier firm's KAM capability. Moreover, different constellations likely exist, because a supplier firm that grants a specific buying firm KA status does not necessarily receive key supplier status in return and vice versa. A deeper understanding of the roles of KAM and KSM capabilities may emerge by studying the different roles of these capabilities in different relationship status constellations. Finally, more research is needed on how a firm's KAM capability is related to, and possible interacts with, the capabilities to manage other customer groups. Since KAM is typically directed at a small percentage of customers in a firm's customer portfolio, most firms also need to develop capabilities to manage customers through classical sales, online channels and other systems. However, the capabilities cannot be deployed independently of each other. They require orchestration, but they also offer potential for learning processes (e.g. Winter, 2000). Hence, future research could study configurations of market-facing capabilities across different customer groups as well as interactions between these capabilities.

\section{Conclusion}

In summary, this study proposes a new perspective on KAM. Arguably, this new perspective is complementary with extant research, yet it provides an important contribution to the study of the strategic role that KAM plays for firm performance. As such, the KAM capability perspective is important because it allows explaining, for example to stakeholders inside and outside a company who are unfamiliar with the details of the KAM concept, why investing into the development of a KAM programme may represent a prerequisite for protecting important relationships and improving financial performance. Moreover, this research provides indications concerning the design of KAM programmes across both the firm level and the relationship level. 
The conceptualization of KAM developed herein differs from the interpretation of the KAM concept that Morgan and Slotegraaf (2012) suggest. In their framework of B2B marketing capabilities, these authors identify KAM as a lower-order capability at the group or team level. We argue that KAM is a strategic concept that firms implement at the level of the organization (i.e. the firm, or a business unit). While in business practice, some firms may implement concepts that they refer to as KAM in an operational, lower-order manner (e.g. some of the KAM types identified by Homburg et al., 2002), from a conceptual point of view, these forms of implementation do not represent an idiosyncratic management concept. They are rather close to classical sales approaches. KAM in essence, however, aims at preserving and extending strategically important firm-customer relationships in the long run and goes beyond single, un-coordinated activities.

We hope that this study contributes to a better understanding of the scope and nature of KAM and provides impetus for future empirical research on the topic. By focusing on the conceptual task in developing a stream of literature discussing supplier firms' KAM capability, we echo the call formulated by Yadav (2010) and other authors who regret the decline of conceptual articles in marketing and encourage scholars to develop frameworks structuring the fields in which empirical research should be conducted subsequently. 


\section{References}

Alhussan, F.B., Al-Husan, F.B., Chavi, C.-Y (2014). Environmental factors influencing the management of key accounts in an Arab Middle Eastern context. Industrial Marketing Management, 43 (4), S592-602.

Araujo, L., Gadde, L. E., \& Dubois, A. (2016). Purchasing and supply management and the role of supplier interfaces. The IMP Journal, 10(1), 2-24.

Atasanova, Y., \& Senn, C. (2011). Global customer team design: Dimensions, determinants, and performance outcomes, Industrial Marketing Management, 40 (2), 278-289.

Augier, M., \& Teece, D. J. (2009). Dynamic capabilities and the role of managers in business strategy and economic performance. Organization Science, 20(2), 410-421.

Arnett, D.B., Macy, B.A., \& Wilcox, J.B. (2005). The role of core selling teams in buyersupplier relationships, Journal of Personal Selling \& Sales Management, XXV(1), 27-42.

Barney, J.B. (1991). Firm resources and sustained competitive advantage. Journal of Management, 17 (1), 99-120.

Becker, M.C. (2004). Organizational routines: a review of the literature. Industrial and corporate change, 13(4), 643-678.

Bozeman, B. (2000). Technology transfer and public policy: a review of research and theory. Research policy, 29 (4), 627-655.

Burkert, M., Ivens, B. S., \& Shan, J. (2012). Governance mechanisms in domestic and international buyer-supplier relationships: An empirical study. Industrial Marketing Management, 41(3), 544-556.

Bush, A.J.; Smart, D.; Nichols, E.L. (2002). Pursuing the concept of marketing productivity, Journal of Business Research, 55, 343-347.

Capaldo, A. (2007). Network structure and innovation: the leveraging of a dual network as a distinctive relational capability. Strategic Management Journal, 28(6), 585-608.

Cheverton, P (2008). No accounting for difference [global account management]. Engineering \& Technology, 3 (7), 78-81.

Collis, D.J. (1994). How valuable are organizational capabilities?, Strategic Management Journal, 15 (8), 143- 152.

Davies, I.A., \& Ryals, L.J. (2013). Attitudes and behaviours of key account managers: Are they really any different to senior sales professionals?, Industrial Marketing Management, 42, 919-931.

Davies, I.A., \& Ryals, L.J. (2014), The effectiveness of key account management practices, Industrial Marketing Management, 43 (7), 1182-1194.

Davies, I.A., Ryals, L.J., Holt, S. (2010), Relationship management: A sales role, or a state of mind? An investigation of functions and attitudes across a business-to-business sales force, Industrial Marketing Management, 39(7), 1049-1062.

Day, G.S. (1994). The capabilities of market-driven organizations, Journal of Marketing, 58 (4), 37-52.

Day, G.S. (2011). Closing the marketing capabilities gap, Journal of Marketing, 75 (4), 183 195. 
Dutta, S., Narasimhan, O.M., \& Rajiv, S. (2005). Research notes and commentaries conceptualizing and measuring capabilities: Methodology and empirical application. Strategic Management Journal, 26(3), 277-285.

Eisenhardt, K.M. \& Martin, J.A. (2000). Dynamic capabilities: What are they? Strategic Management Journal, 21(10), 1105-1121.

Fahy, J., Hooley, G., Cox, T., Beracs, J., Fonfara, K., \& Snoj, B. (2000). The development and impact of marketing capabilities in Central Europe. Journal of International Business Studies, 31 (1), 63-81.

Ford, D., Gadde, L.E., Hakansson, H., \& Snehota, I. (2003). Managing Business Relationships: Wiley \& Sons Ltd, Chichester, England.

Friend, S.B., \& Johnson, J.S. (2014). Key account relationships: An exploratory inquiry of customer-based evaluations, Industrial Marketing Management, 43 (4), 642-658.

Emerson, R. M. (1981). Social exchange theory. In Social Psychology: Sociological Perspectives, ed. M. Rosenberg,R. Turner, pp. 30-65. New York: Academic.

Feldman, M. S., \& Pentland, B. T. (2003). Reconceptualizing organizational routines as a source of flexibility and change. Administrative Science Quarterly, 48(1), 94-118.

Forkmann, S., Henneberg, S., Naude, P., \& Mitrega, M. (2016). Supplier Relationship Management Capability: A Qualification and Extension", Industrial Marketing Management, 57, 185-200.

Gao, T., \& Hui Shi, L. (2011). How do multinational suppliers formulate mechanisms of global account coordination? An integrative framework and empirical study. Journal of International Marketing, 19(4), 61-87.

Geigenmüller, A., \& Leischnig, A. (2017). A configurational perspective on alliance management capabilities. in: Das, T. K. (Ed.), Managing alliance portfolios and networks. Information Age Publishing, forthcoming.

Georges, L., \& Eggert, A. (2003). Key account managers' role within the value creation process of collaborative relationships. Journal of Business to Business Marketing, 10(4), 122.

Goffman, E. (1974). Frame analysis, Cambridge: Harvard University Press.

Gounaris, S., \& Tzemeplikos, N. (2014). Relational key account management: Building key account management effectiveness through structural reformations and relationship management skills, Industrial Marketing Management, 44 (7), 1110-1123.

Greenley, G.E., Hooley, G.J., \& Rudd, J.M. (2005). Market orientation in a multiple stakeholder orientation context: implications for marketing capabilities and assets. Journal of Business Research, 58 (11), 1483-1494.

Gu, F. F., Hung, K., \& Tse, D. K. (2008). When does guanxi matter? Issues of capitalization and its dark sides. Journal of Marketing, 72(4), 12-28.

Guenzi, P., \& Storbacka, K. (2015). The organizational implications of implementing key account management: A case-based examination, Industrial Marketing Management, 45 (2), 84-97.

Guesalaga, R. (2014). Top management involvement with key accounts. The concept, its dimensions, and strategic outcomes, Industrial Marketing Management, 43 (7), 1146-1156. 
Guesalaga, R., \& Johnston, W. (2010), What's next in key account management research? Building the bridge between the academic literature and the practitioners' priorities, Industrial Marketing Management, 39 (7), 1063-1068.

Hakanen, T. (2014), "Co-creating integrated solutions within business networks. The KAM team as knowledge integrator," Industrial Marketing Management, 43 (7), 1195-1203.

Hakansson, H. \& Snehota, I. (1995). Developing Relationships in Business Networks, London : Routledge.

Havila, V., \& Medlin, C.J. (2012). Ending-competence in business closure. Industrial Marketing Management, 41(3), 413-420.

Helfat, C.E., \& Winter, S.G. (2011). Untangling dynamic and operational capabilities: Strategy for the (n)ever-changing world, Strategic Management Journal, 32 (11), 12431250.

Henneberg, S.C., Mouzas, S., \& Naudé, P. (2006). Network pictures: concepts and representations. European Journal of Marketing, 40(3/4), 408-429.

Henneberg, S. C., Pardo, C., Mouzas, S., \& Naudé, P. (2009). Value dimensions and relationship postures in dyadic 'Key Relationship Programmes'. Journal of Marketing Management, 25(5-6), 535-550.

Homburg, C., Cannon, J. P., Krohmer, H., \& Kiedaisch, I. (2009). Governance of international business relationships: A cross-cultural study on alternative governance modes. Journal of International Marketing, 17(3), 1-20.

Homburg, C., Wieseke, J., \& Bornemann, T. (2009). Implementing the marketing concept at the employee-customer interface: the role of customer need knowledge. Journal of Marketing, 73 (4), 64-81.

Homburg, C., Workman Jr, J. P., \& Jensen, O. (2002). A configurational perspective on key account management. Journal of Marketing, 66 (2), 38-60.

Hooley, G.J., Broderick, A., \& Möller, K. (1998). Competitive positioning and the resourcebased view of the firm. Journal of Strategic Marketing, 6(2), 97-116.

Hooley, G.J., Greenley, G.E., Cadogan, J.W., \& Fahy, J. (2005). The performance impact of marketing resources. Journal of Business Research, 58 (1), 18-27.

Hooley, G.J., Saunders, J.A., Piercy, N.F. (2008). Marketing Strategy and Competitive Positioning. Harlow : Prentice Hall.

Hui Shi, L., Zou, S., \& Cavusgil, S.T. (2004). A conceptual framework of global account management capabilities and firm performance. International Business Review, 13(5), 539-553.

Hult, G.T.M. (2011). Toward a theory of the boundary-spanning marketing organization and insights from 31 organization theories. Journal of the Academy of Marketing Science, 39 (August), 509-536.

Hunt, S. D. (1983). General theories and the fundamental explananda of marketing. Journal of Marketing, 47 (4), 9-17.

Hunt, S.D. (2000). A general theory of competition: Resources, competences, productivity, economic growth, Sage Publications.

Ivens, B.S., Niersbach, B., \& Pardo, C. (2015). Key Account Management: Selling? Providing Services? ... Or Both?, Marketing Review St. Gallen, 32 (6), 17-24. 
Ivens, B.S., \& Pardo, C. (2007). Are key account relationships different? Empirical results on supplier strategies and customer reactions. Industrial Marketing Management, 36(4), 470482.

Ivens, B.S., \& Pardo, C. (2015). Managerial Implications of Research on Inter-organizational Interfaces: The Case of Key Account Management, The IMP Journal, 10(1), 25-49.

Ivens, B. S., Pardo, C., Niersbach, B., \& Leischnig, A. (2016). Firm-internal key account management networks: Framework, case study, avenues for future research. Industrial Marketing Management, 58, 102-113.

Ivens, B.S., Pardo, C., Salle, R., \& Cova, B. (2009). Relationship keyness: The underlying concept for different forms of key relationship management. Industrial Marketing Management, 38(5), 513-519.

Ivens, B.S., Van de Vijver, M., \& Vos, B. (2013). Managing and developing key supplier relationships. Industrial Marketing Management, 42(2), 135-138.

Järvensivu, T., \& Möller, K. (2009). Metatheory of network management: A contingency perspective. Industrial Marketing Management, 38(6), 654-661.

Kale, P., Dyer, J.H., \& Singh, H. (2002). Alliance capability, stock market response, and long-term alliance success: the role of the alliance function. Strategic Management Journal, 23(8), 747-767.

Kale, P., \& Singh, H. (2007). Building firm capabilities through learning: the role of the alliance learning process in alliance capability and firm - level alliance success. Strategic Management Journal, 28 (10), 981-1000.

Kenny, B., \& Fahy, J. (2013). The role of tie strength, relational capability and trust in the international performance of high tech SMEs. The IMP Journal, 7(3), 188-203.

Lacoste, S., \& Blois, K. (2015). Suppliers' power relationships with industrial key customers, Journal of Business \& Industrial Marketing, 30 (5), 562-571.

Lai, C. J., \& Gelb, B. D. (2015). Key account teams: success factors for implementing strategy. Journal of Business Strategy, 36(4), 48-55.

Lavie, D. (2007). Alliance portfolios and firm performance: A study of value creation and appropriation in the US software industry. Strategic Management Journal, 28(12), 11871212.

Lawrence, P.R., \& Lorsch, J.W. (1967). Differentiation and integration in complex organizations, Administrative Science Quarterly, 12, 1-47.

Leischnig, A., Ivens, B.S., Niersbach, B., \& Pardo, C. (2017). Mind the gap: A process model for diagnosing barriers to key account management implementation. Industrial Marketing Management, forthcoming.

Leischnig, A., Geigenmüller, A., \& Lohmann, S. (2014). On the role of alliance management capability, organizational compatibility, and interaction quality in interorganizational technology transfer. Journal of Business Research, 67 (6), 1049-1057.

Leischnig, A., \& Kasper-Brauer, K. (2016). How to sell in diverse markets? A two-level approach to industry factors and selling factors for explaining firm profitability. Journal of Business Research, 69(4), 1307-1313.

Levitt, B., \& March, J.G. (1988). Organizational learning. Annual Review of Sociology, 14, 319-340. 
Makkonen, H., \& Olkkonen, R. (2013). The conceptual locus and functionality of key supplier management: A multi-dyadic qualitative study. Industrial Marketing Management, 42(2), 189-201.

Marcos-Cuevas, J.M., Nätti, S., Palo, T., \& Ryals, L.J. (2014). Implementing key account management: Intra-organizational practices and associated dilemmas, Industrial Marketing Management, 43 (7), 1216-1224.

McGrath, H., \& O'Toole, T. (2013). Enablers and inhibitors of the development of network capability in entrepreneurial firms: A study of the Irish micro-brewing network. Industrial Marketing Management, 42(7), 1141-1153.

Michailova, S., \& Worm, V. (2003). Personal Networking in Russia and China::: Blat and Guanxi. European Management Journal, 21(4), 509-519.

Millman, T., \& Wilson, K. (1996). Developing key account management competences. Journal of Marketing Practice: Applied Marketing Science, 2(2), 7-22.

Mitrega, M., Forkmann, S., Ramos, C., \& Henneberg, S. C. (2012). Networking capability in business relationships-Concept and scale development. Industrial Marketing Management, 41(5), 739-751.

Mitrega, M., Forkmann, S., Zaefarian, G., \& Henneberg, S. C. (2017). Networking capability in supplier relationships and its impact on product innovation and firm performance. International Journal of Operations \& Production Management, 37(5), 577-606.

Morgan, N.A., Katsikeas, C.S., \& Vorhies, D.W. (2012). Export marketing strategy implementation, export marketing capabilities, and export venture performance. Journal of the Academy of Marketing Science, 40(2), 271-289.

Morgan, N. A., \& Slotegraaf, R. J. (2012). Marketing capabilities for B2B firms, in Lilien, G.L. \& Grewal, R. (eds.): Handbook on Business-to-Business Marketing, Northampton, MA: Edward Elgar Publishers, 90-108.

Morgan, R.M., \& Hunt, S.D. (1994), The Commitment-Trust Theory of Relationship Marketing, Journal of Marketing, 58 (July), 20-38.

Nelson, R., Winter, S. (1982). An Evolutionary Theory of Economic Change. Belknap Press: Cambridge, MA.

Ojasalo, J. (2001). Key account management at company and individual levels in business-tobusiness relationships. Journal of Business \& Industrial Marketing, 16(3), 199-220.

Pardo, C. (1999). Key account management in the business-to-business field: a French overview. Journal of Business \& Industrial Marketing, 14(4), 276-297.

Pardo, C., Henneberg, S.C., Mouzas, S., \& Naudè, P. (2006). Unpicking the meaning of value in key account management. European Journal of Marketing, 40 (11/12), 1360-1374.

Pardo, C., Ivens, B. S., \& Wilson, K. (2013). Assessing and strengthening internal alignment of new marketing units: An interpretative tool. Industrial Marketing Management, 42 (7), 1074-1082.

Pardo, C., Ivens, B. S., \& Wilson, K. (2014). Differentiation and alignment in KAM implementation. Industrial Marketing Management, 43(7), 1136-1145.

Penrose, E.T. (1959). The Theory of the Growth of the Firm. Wiley: New York.

Peteraf, M.A. (1993). The cornerstones of competitive advantage. Strategic Management Journal, 14 (3), 179-191. 
Piercy, N. F., \& Lane, N. (2006). The hidden risks in strategic account management strategy. Journal of Business Strategy, 27(1), 18-26.

Pressey, A. D., Gilchrist, A. J., \& Lenney, P. (2014), Sales and marketing resistance to Key Account Management implementation. An ethnographic investigation, Industrial Marketing Management, 43 (7), 1157-1171.

Ragin, C. C. (2008). Redesigning social inquiry: Fuzzy sets and beyond (Vol. 240). Chicago: University of Chicago Press.

Richard, K.A., \& Jones, E. (2009). Key Account Management: Adding elements,of account fit to an integrative theoretical framework, Journal of Personal Selling \& Sales Management, XXIX (4), 305-320.

Ring, P.S., \& Van de Ven, A.H. (1994), Developmental processes of cooperative interorganizational relationships, Academy of Management Review, 19 (1), 90-118.

Ritter, T., \& Geersbro, J. (2011). Organizational relationship termination competence: A conceptualization and an empirical test. Industrial Marketing Management, 40(6), 988-993.

Ritter, T., Wilkinson, I.F., \& Johnston, W.J. (2002). Measuring network competence: Some international evidence, Journal of Business and Industrial Marketing, 17 (2/3), 119-138

Schilke, O. (2014a). Second-order dynamic capabilities: How do they matter?, Academy of Management Perspectives , 28 (4), 368-380.

Schilke, O. (2014b). On the contingent value of dynamic capabilities for competitive advantage: The nonlinear moderating effect of environmental dynamism, Strategic Management Journal, 35 (2), 179-203.

Sengupta, S., Krapfel, R. E., \& Pusateri, M. A. (2000). An empirical investigation of key account salesperson effectiveness. Journal of Personal Selling \& Sales Management, 20, $253-261$.

Speakman, J.I.F., \& Ryals, L.J. (2012). Key account management: the inside selling job, Journal of Business \& Industrial Marketing, (27/5), 360-369.

Storbacka, K. (2012), Strategic account management programs: alignment of design elements and management practices, Journal of Business \& Industrial Marketing, 27 (4), 259-274.

Srivastava, R. K., Shervani, T. A., \& Fahey, L. (1998). Market-based assets and shareholder value: A framework for analysis. Journal of Marketing, 62(1), 2-18.

Srivastava, R.K., Shervani, T.A., Fahey, L. (1999). Marketing, Business Processes, and Shareholder Value: An Organizationally Embedded View of Marketing Activities and the Discipline of Marketing, Journal of Marketing, 63 (Special Issue 1999), 168-179.

Suddaby, R. (2010). Editor's comments: Construct clarity in theories of management and organization, Academy of Management Review, 35 (3), 346-357.

Sullivan, U.Y., Peterson, R.M., \& Krishnan, V. (2012). Value creation and firm sales performance. The mediating roles of strategic account management and relationship perception, Industrial Marketing Management, 41 (1), 166-173.

Teece, D. J. (2007). Explicating dynamic capabilities: the nature and micro of (sustainable) enterprise performance. Strategic Management Journal, 28(13), 1319-1350.

Teece, D. J. (2012). Dynamic capabilities: Routines versus entrepreneurial action. Journal of Management Studies, 49(8), 1395-1401. 
Teece, D., \& Pisano, G. (1994). The dynamic capabilities of firms: an introduction. Industrial and Corporate Change, 3(3), 537-556.

Teece, D. J., Pisano, G., \& Shuen, A. (1997). Dynamic capabilities and strategic management, Strategic Management Journal, 18 (7), 509-533.

Thornton, S.C., Henneberg, S.C., \& Naudé, P. (2014). Conceptualizing and validating organizational networking as a second-order formative construct. Industrial Marketing Management, 43(6), 951-966.

Tóth, Z., Thiesbrummel, C., Henneberg, S.C., \& Naudé, P. (2015). Understanding configurations of relational attractiveness of the customer firm using fuzzy set QCA. Journal of Business Research, 68(3), 723-734.

Ulaga, W., \& Eggert, A. (2006). Value-based differentiation in business relationships: Gaining and sustaining key supplier status. Journal of Marketing, 70(1), 119-136.

Ulrich, D., \& Lake, D.G. (1990). Organizational capability: Competing from the inside out. John Wiley \& Sons.

Vafeas, M. (2015). Account manager turnover and the influence of context: an exploratory study, Journal of Business \& Industrial Marketing, 30 (1), 72-82.

Vorhies, D.W., Orr, L.M., \& Bush, V.D. (2011). Improving customer-focused marketing capabilities and firm financial performance via marketing exploration and exploitation. Journal of the Academy of Marketing Science, 39(5), 736-756.

Vorhies, D.W., \& Morgan, N.A. (2005). Benchmarking marketing capabilities for sustainable competitive advantage, Journal of Marketing, 69 (1), 80-94.

Wagner, S. M. (2006). A firm's responses to deficient suppliers and competitive advantage. Journal of Business Research, 59(6), 686.

Winter, S.G. (2000). The satisficing principle in capability learning. Strategic Management Journal, 21(10-11), 981-996.

Winter, S.G. (2003). Understanding dynamic capabilities, Strategic Management Journal, 24, 991-995.

Workman, J.; Homburg, C.; \& Jensen, O. (2003). Intraorganizational determinants of key account management effectiveness. Journal of the Academy of Marketing Science, 31(1), $3-21$.

Yadav, M.S. (2010), The decline of conceptual articles and implications for knowledge development, Journal of Marketing, 74 (1), 1-19.

Zaefarian, G., Forkmann, S., Mitrega, M., \& Henneberg, S. (2016). A Capability Perspective on Relationship Ending and its Impact on Product Innovation Success and Firm Performance, Long Range Planning, in press.

Zahra, S.A., Sapienza, H.J., \& Davidsson, P. (2006). Entrepreneurship and dynamic capabilities: A review, model and research agenda. Journal of Management Studies, 43 (4), 917-955.

Zhang, C., Viswanathan, S., \& Henke, J.W. (2011). The boundary spanning capabilities of purchasing agents in buyer-supplier trust development. Journal of Operations Management, 29(4), 318-328.

Zhang, Q., Vonderembse, M.A., \& Lim, J.S. (2002). Value chain flexibility: a dichotomy of competence and capability. International Journal of Production Research, 40 (3), 561-583. 
Zollo, M., \& Winter, S. G. (2002). Deliberate learning and the evolution of dynamic capabilities. Organization science, 13(3), 339-351. 
Table 1: A firm's KAM capability and its specific KAM capability building blocks

\begin{tabular}{|c|c|c|}
\hline & $\begin{array}{c}\text { Relationship-level capability } \\
\text { (substantive capability and/or } \\
\text { dynamic capability) }\end{array}$ & $\begin{array}{c}\text { Programme-level capability } \\
\text { (substantive capability and/or } \\
\text { dynamic capability) }\end{array}$ \\
\hline $\begin{array}{l}\text { KAM outside- } \\
\text { in capability }\end{array}$ & $\begin{array}{l}\text { - KA customer sensing } \\
\text { - KA customer linking }\end{array}$ & $\begin{array}{l}\text { - } \text { Market sensing } \\
\text { - Competitor monitoring }\end{array}$ \\
\hline $\begin{array}{l}\text { KAM spanning } \\
\text { capability }\end{array}$ & $\begin{array}{l}\text { - Account-specific strategic planning } \\
\text { - Account-specific value proposition (incl. pricing, } \\
\text { customer service, product/service adaptation, } \\
\text { logistics adaptation, etc.) } \\
\text { - Management of joint projects } \\
\text { - Information dissemination between both firms } \\
\text { - Management of contacts and interactions across } \\
\text { and between both firms }\end{array}$ & $\begin{array}{l}\text { - General KAM strategy development } \\
\text { - KAM customer portfolio definition } \\
\text { - KAM-related information dissemination } \\
\text { - Definition of KAM processes and structures } \\
\text { - Definition of actors involved in KA-directed } \\
\text { activities }\end{array}$ \\
\hline $\begin{array}{l}\text { KAM inside- } \\
\text { out capability }\end{array}$ & $\begin{array}{l}\text { - Relationship specific cost and revenue control } \\
\text { - Technology matching and presentation }\end{array}$ & $\begin{array}{l}\text { - Technology development for KA customers } \\
\text { - Flexible manufacturing processes for KA } \\
\text { customers } \\
\text { - Flexible supply chain management for KA } \\
\text { customers } \\
\text { - KAM programme cost and revenue control }\end{array}$ \\
\hline
\end{tabular}

KAM support
capabilities

- Information systems, HR management, administration, finance, legal, CSR etc. 